ISSN 1392-3196 / e-ISSN 2335-8947

Zemdirbyste-Agriculture, vol. 102, No. 1 (2015), p. 67-72

DOI 10.13080/z-a.2015.102.008

\title{
The effects of soil tillage and crop rotation on the development of winter wheat leaf diseases
}

\author{
Biruta BANKINA ${ }^{1}$, Antons RUŽA², Līga PAURA³ ${ }^{3}$ Ilze PRIEKULE ${ }^{4}$ \\ ${ }^{1}$ Institute of Soil and Plant Sciences, Latvia University of Agriculture \\ Lielā 2, Jelgava, Latvia \\ E-mail: biruta.bankina@1lu.lv \\ ${ }^{2}$ Institute of Agrobiotechnology, Latvia University of Agriculture \\ Lielā 2, Jelgava, Latvia \\ ${ }^{3}$ Department of Control Systems, Latvia University of Agriculture \\ Lielā 2, Jelgava, Latvia \\ ${ }^{4}$ UAB Makhteshim-Agan Benelux and Nordic \\ Ulonų 2, Vilnius, Lithuania
}

\begin{abstract}
Winter wheat is one of the most profitable crops in Latvia. Different growing technologies, including reduced soil tillage and continuous wheat sowing, have become more popular in recent years. The aim of this study was to characterise the development of winter wheat leaf diseases with respect to the soil tillage method and crop rotation under typical wheat growing conditions in the central region of Latvia. Experiments were carried out at the Pēterlauki Study and Research Farm of Latvia University of Agriculture in 2010, 2012 and 2013. Trials were conducted in two blocks: 1) conventional tillage with mouldboard ploughing at a depth of 22-23 cm and 2) reduced tillage with disc harrowing at a depth of 10-12 cm. Different crop rotations were established in each block, but crop sequences differed slightly depending on the year. Continuous wheat sowing and reduced soil tillage increased the level of tan spot infection, especially when these two factors were combined. The level of infection with Septoria leaf blotch was influenced by the soil tillage method and the year.
\end{abstract}

Key words: Pyrenophora tritici-repentis, reduced soil tillage, Zymoseptoria tritici.

\section{Introduction}

Winter wheat is one of the most profitable crops in Latvia, especially in the central part of Latvia, where the most fertile soils are located. Leaf diseases are important risk factors for wheat grain production. Different growing technologies, especially reduced soil tillage and monoculture of wheat, affect the development of diseases, but systematic investigations were not conducted in Latvia until 2010.

Tan spot, caused by Pyrenophora tritici-repentis, and Septoria leaf blotch, caused by Zymoseptoria tritici, are the most widespread wheat leaf diseases. The severity of rusts and mildew is significantly lower in most of the cases in Latvia. Plant residues on the soil surface are the main source of infection. Many pathogens continue to sporulate on the plant debris if it is not buried in the soil (Krupinsky et al., 2007 b). Wheat straw residues used in the conservation tillage system are considered to be the main factor influencing the risk of tan spot (Schuh, 1990; Carignano et al., 2008). The strong influence of crop rotation on the level of tan spot was proved in the
United States of America, where tan spot was a dominant wheat disease. Growing alternative previous crops significantly decreased the severity of leaf blotch under no-till management conditions (Krupinsky et al., 2007 b). Continuous wheat sowings increased development of leaf blotch, especially tan spot, but did not affect diseases caused by biotrophs. The higher severity of mildew was observed on the plants grown after oilseed rape compared with the wheat grown after wheat. Development of brown rust did not depend on the pre-crop, but the influence of cultivars was significant (Wyczling et al., 2010). Similar results were obtained by Polish researchers. Higher mildew severity was reported on wheat plants grown after pea compared with continuously grown wheat. In contrast, tan spot severity was higher in continuous wheat, whereas the results regarding Septoria leaf blotch development were contradictory depending on the year (Sawinska et al., 2006). Most researchers indicate that intensive winter wheat production and non-inversion tillage are the most important factors influencing the 
severity of tan spot (Jørgensen, Olsen, 2007). However, effect of soil tillage is affected by crop rotation and vice versa. Mouldboard ploughing reduces the severity of tan spot in continuous wheat production in comparison with other soil tillage systems (Bockus, Claassen, 1992). Nevertheless, conventional soil tillage is not a universally effective method of leaf disease control. For example, mouldboard ploughing did not reduce the severity of wheat leaf diseases in Poland (Sawinska et al., 2006).

The influence of the soil tillage system can be minimised by meteorological conditions. In dry years, the pressure of diseases was low, and non-tillage did not increase the level of tan spot (Krupinsky et al., 2007 a). Various investigations related to disease development and agronomic measures have been conducted across the world, but the conclusions drawn were inconsistent.

The aim of this study was to characterise the development of winter wheat leaf diseases with respect to the soil tillage method and crop rotation.

\section{Materials and methods}

A long-term field experiment was established at the Pēterlauki Study and Research Farm of Latvia University of Agriculture. Between 2010 and 2013, trials were conducted in two blocks: 1) conventional tillage with mouldboard ploughing at a depth of $22-23 \mathrm{~cm}$ and 2) reduced tillage with disc harrowing at a depth of 10 $12 \mathrm{~cm}$. Different crop rotations were established in each block, but crop sequences differed slightly depending on the year: 1) winter wheat after spring or winter oilseed rape, 2) winter wheat after winter wheat. The trial conditions were very similar to actual crop production conditions; the total plot area was 6 ha, and the area for each treatment was 0.25 ha.

Altogether, 12 plots of winter wheat were surveyed each year. The cultivar 'Zentos' was used every year. This cultivar is popular because it is productive and medium resistant against diseases and has good winter hardiness. The incidence and severity of diseases were assessed for each plot. Wheat plots were categorised according to the previous crop and the soil tillage system. A similar method was used by Fernandez et al. (2009). Data of disease development in 2010, 2012 and 2013 was used to evaluate different technologies. The results from 2011 were excluded due to the extremely bad overwintering, when part of the winter wheat fields were reseeded with spring wheat. Diseases were assessed weekly. The incidence and severity of the disease were noted for the whole plant until growth stage 31, for the 3 upper leaves until growth stages 32-69, and for the 2 upper leaves until later stages. Growth stages were noted according to $\mathrm{BBCH}$ scale.

The total impact of the diseases during the vegetation period was estimated by calculating the area under the disease progress curve (AUDPC). For statistical analyses of the total impact of the diseases, expressed as the value of AUDPC, a three-way analysis of variance (ANOVA) was performed, which included year $(i=1$ ... 3), crop rotation (continuous wheat sowing/pre-crop other than wheat) and soil tillage method (conventional ploughing/reduced tillage). The efficiency of various combinations of crop rotation and soil tillage method (continuous wheat and ploughing, other pre-crop and ploughing, continuous wheat and reduced tillage, and other pre-crop and reduced tillage) and the influence of year was analysed by two-factor ANOVA. The factor was considered statistically significant when $p<0.05$. All agronomic measures were applied uniformly, according to the requirements of agronomic practice in Central Latvia. Foliar fungicides (epoxiconazole $84 \mathrm{~g} \mathrm{~L}^{-1}$ and fenpropiomorph $150 \mathrm{~g} \mathrm{~L}^{-1}, 1.5 \mathrm{~L} \mathrm{ha}^{-1}$ ) were sprayed across all wheat plots at the heading stage.

Themeteorological conditions differed during the investigations. Temperatures fluctuated around the longterm average. Observed deviations were not recognised as an important factor influencing the development of diseases. However, the level of precipitation was significantly different in May and June, the time of stem elongation and heading, which is the most crucial period for the spread of leaf diseases (Fig. 1).

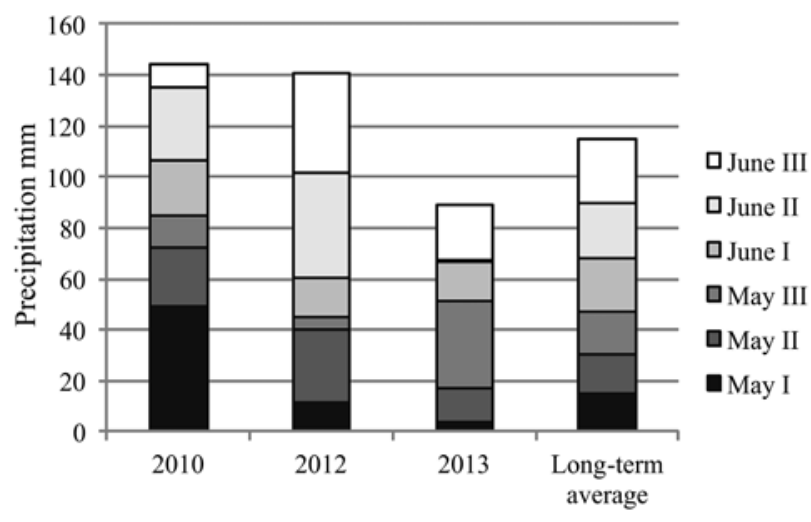

Figure 1. Precipitation during the crucial period of wheat leaf disease spread in Pēterlauki, Latvia

The total amount of precipitation was higher in 2010 and 2012 compared with the long-term average in this period. The first ten-day period of May was significantly more humid in 2010, particularly compared with 2013.

\section{Results}

Tan spot, caused by Pyrenophora tritici-repentis, and Septoria leaf blotch, caused by Zymoseptoria tritici, were the most prevalent wheat leaf diseases during the study. Mildew, caused by Blumeria graminis, was observed in the majority of wheat plots. Although the incidence of mildew fluctuated from $1 \%$ to $45 \%$, the severity of this disease was low and did not exceed $0.5 \%$ in any plot. The dynamics of tan spot feature development were affected by the crop rotation and soil tillage method (Fig. 2). The severity of the first symptoms differed sharply depending on the technologies. Reduced soil tillage in combination with continuous wheat sowing promoted the development of more severe symptoms in the spring and during the whole vegetation season. 


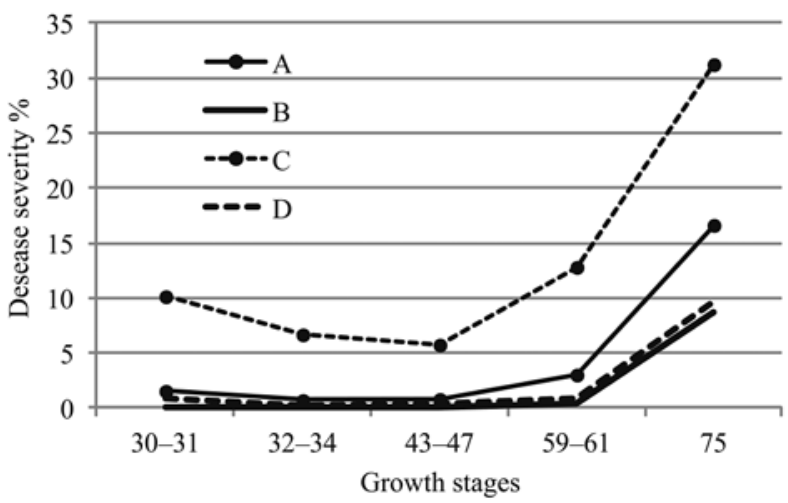

A - continuous wheat and ploughing, B - other pre-crop and ploughing, $\mathrm{C}$ - continuous wheat and reduced tillage, $\mathrm{D}$ - other pre-crop and reduced tillage

Figure 2. Dynamics of tan spot development in winter wheat cv. 'Zentos' with respect to the technologies used (data represents the average)

The influence of continuous sowing and soil tillage on the severity of Septoria leaf blotch and mildew was not clearly noticeable. The total impact of tan spot (expressed as the AUDPC value) was not significantly affected by the year, but pre-crop $(p<0.01)$ and soil tillage $(p<0.05)$ influenced the development of this disease (Fig. 3).

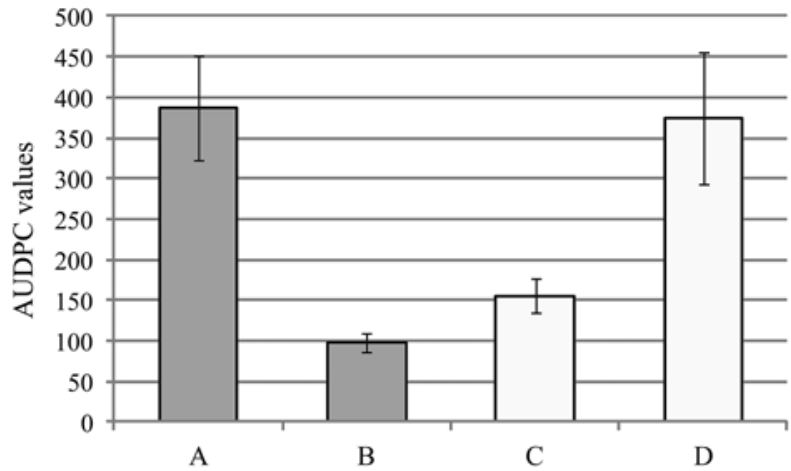

A - continuous wheat fields, B - other pre-crop fields, C ploughing fields, D - reduced tillage fields

Figure 3. Values of tan spot area under the disease progress curve (AUDPC) in winter wheat cv. 'Zentos' with respect to the technologies used

Severity of Septoria leaf blotch was influenced by the year $(p<0.05)$ and soil tillage $(p<0.1)$ but not by pre-crop (Fig. 4).

Disease development was influenced by the combination of agrotechnical measures $(p<0.01)$, namely, crop rotation and soil tillage (Figs 5 and 6 ). The level of tan spot was significantly higher if reduced soil tillage was combined with continuous sowing of wheat. Conventional ploughing essentially decreased the severity of tan spot, even in continuous wheat sowings. Crop rotation is the most important agrotechnological measure to control tan spot in both cases, irrespective of the soil tillage method.



Figure 4. Values of Septoria leaf blotch area under the disease progress curve (AUDPC) in winter wheat cv. 'Zentos' with respect to the soil tillage and year

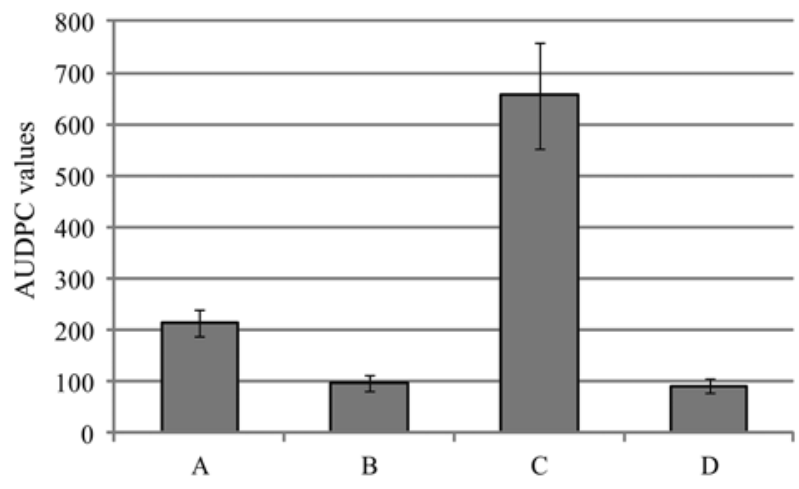

A - ploughing and continuous wheat plots, $\mathrm{B}$ - ploughing and other pre-crop plots, $\mathrm{C}$ - reduced tillage and continuous wheat plots, D - reduced tillage and other pre-crop plots

Figure 5. Tan spot area under the disease progress curve (AUDPC) values in winter wheat cv. 'Zentos' with respect to the technologies used



A - ploughing and continuous wheat plots, $\mathrm{B}$ - ploughing and other pre-crop plots, $\mathrm{C}$ - reduced tillage and continuous wheat plots, D - reduced tillage and other pre-crop plots

Figure 6. Septoria leaf blotch area under the disease progress curve (AUDPC) values in winter wheat cv. 'Zentos' with respect to the technologies used 
The development of Septoria leaf blotch was not strongly correlated with the agrotechnical methods used. A significant difference was observed only between the plots in which conventional soil tillage was combined with continuous wheat sowing and those in which reduced soil tillage was combined with continuous wheat sowing. The level of mildew was low; therefore, clear regularity was not established, but some tendencies were observed. The progression of mildew was influenced only by the year, and the pre-crop and soil tillage method were not influential factors. The severity of this disease was observed to be slightly higher in the conventionally ploughed fields when compared with reduced tillage fields.

\section{Discussion}

For the last couple of years, leaf blotches (caused by Pyrenophora tritici-repentis and Zymoseptoria tritici) have been dominant in Latvia. Mildew is observed frequently, but this disease is rarely devastating, whereas rusts occur only in a small minority of cases. A similar situation has also been noted in these trials; therefore, investigation of the influence of different agronomic measures on the development of this disease group is very important.

The influence of agrotechnical measures on the epidemiological situation in the winter wheat fields depends on the dominant disease in a particular year, because the peculiarities of tan spot and Septoria leaf blotch development are different. The development of tan spot clearly depends on agrotechnical measures. The severity of the first symptoms of this disease is higher in plots that lack crop rotation and reduced soil tillage. Our results confirmed the importance of the level of primary inoculums in the development of tan spot. The significance of ploughing under wheat monoculture was observed in Argentina, where reduction of wheat debris by ploughing decreased the level of disease if the prevalent disease was tan spot (Simon et al., 2011). Both investigated factors - soil tillage systems and crop rotation - are important measures to control tan spot, but combinations of these two factors (reduced soil tillage and lack of crop rotation) significantly increase the risk of tan spot. Similar results were obtained by other researchers - continuous wheat sowing combined with reduced tillage significantly increased the level of tan spot (Bockus, 1998; Ronis et al., 2009).

Nevertheless, differentresults have been obtained across the world. Bailey and Duczek (1996) noted the importance of variable meteorological conditions, which can minimise the differences in soil tillage systems. Also, Fernandez et al. (2009) did not find a correlation between the level of leaf blotches and the soil tillage system or cropping sequence. A similar situation was observed in Canada, where wheat leaf spot diseases were not affected by soil tillage systems in any of the years during a fouryear study (Kutcher et al., 2011). Bailey et al. (2001) did not find a correlation between the wheat leaf disease severity and the soil treatment, except in certain years. Annual environmental factors have been found to be the most important factors influencing the severity of wheat diseases. Krupinsky and Tanaka (2001) noted the influence of environmental factors: in years favourable for leaf disease development, the lowest level of disease was observed under conventional soil tillage; but in years with low disease pressure, this trend was not observed.

Differences in the obtained results could possibly be explained by the different spectrum of diseases. The level of tan spot was not essentially influenced by different meteorological situations during the study, but the method of soil tillage and the pre-crop were important. The converse situation was observed if Septoria leaf blotch was the dominant disease. The year significantly influenced the development of Septoria leaf blotch in our investigations. The highest AUDPC value was obtained in 2010, when an extremely high amount of precipitation occurred in May and June. The conditions are especially important in the first half of May, during stem elongation, which is the crucial period of this disease's development. The importance of rain splash for the development of this disease is widely known, and different studies across the world have demonstrated this relationship (Gladders et al., 2001).

The highest level of tan spot was observed in plots where a lack of crop rotation was combined with reduced soil tillage. We did not have sufficient data concerning mildew development with respect to the technologies, because the level of this disease was too low. Nevertheless, a tendency toward a higher level of mildew was observed under better wheat-growing conditions - crop rotation and conventional ploughing promoted the development of this disease. Reduced soil tillage combined with a lack of crop rotation significantly increased the risk of tan spot development. The relevant Septoria leaf blotch results were inconclusive. Further investigations are necessary to evaluate the significance of the pre-pre-crop and continuous usage of the reduced soil tillage system.

\section{Conclusions}

1. Tan spot, caused by Pyrenophora triticirepentis, and Septoria leafblotch, caused by Zymoseptoria tritici, were the most widespread and devastating diseases of winter wheat in Latvia.

2. Development of tan spot was significantly influenced by the crop rotation and soil tillage method. The highest level of wheat diseases was observed when continuous wheat was grown under reduced soil tillage.

3. Development of Septoria leaf blotch was influenced by the year and the soil tillage system. The previous crop did not significantly affect the level of disease. 


\section{Acknowledgements}

The research was funded by the State Research Programme "Sustainable use of local resources (earth, food and transport) - new products and technologies (NatRes)", 2010-2013, project No. 3: "Sustainable use of local agricultural resources for development of high nutritive value food products (Food)" and by a grant from the Ministry of Agriculture "Influence of minimal soil tillage on its fertility maintenance, development and distribution of pests as well as crops' yield and quality in resowings".

Received 10032014

Accepted 14092014

\section{References}

Bailey K. L., Duczek L. J. 1996. Managing cereal diseases under reduced tillage. Canadian Journal of Plant Pathology, 18: 159-167 http://dx.doi.org/10.1080/07060669609500641

Bailey K. L., Gossen B. D., Lafond G. P., Watson P. R., Derksen D. A. 2001. Effect of tillage and crop rotation on root and foliar diseases of wheat and pea in Saskatchewan from 1991 to 1998: univariate and multivariate analyses. Canadian Journal of Plant Sciences, 81 (4): 789-803 http://dx.doi.org/10.4141/P00-152

Bockus W. W. 1998. Control strategies for stubble-borne pathogens of wheat. Canadian Journal of Plant Pathology, 20: $371-375$ http://dx.doi.org/10.1080/07060669809500405

Bockus W. W., Claassen M. M. 1992. Effects of crop rotation and residue management practices on severity of tan spot of winter wheat. Plant Disease, 76: 633-636 http://dx.doi.org/10.1094/PD-76-0633

Carignano M., Staggenborg S. A., Shroyer J. P. 2008. Management practices to minimize tan spot in a continuous wheat rotation. Agronomy Journal, 100 (1): 145-153 http://dx.doi.org/10.2134/agrojnl2007.0092

Fernandez M. R., Pearse P. G., Holzgang G., Basnyat P., Zentner R. P. 2009. Impacts of agronomic practices on the leaf spotting complex of common wheat in eastern Saskatchewan. Canadian Journal of Plant Sciences, 89 (4): $717-730$ http://dx.doi.org/10.4141/CJPS08140

Gladders P., Paveley N. D., Barrie I. A., Hardwick N. V., Hims M. J., Langton S., Taylor M. C. 2001. Agronomic and meteorological factors affecting the severity of leaf blotch caused by Mycosphaerella graminicola in commercial wheat crops in England. Annals of Applied Biology, 138 (3): 301-311 http://dx.doi.org/10.1111/j.1744-7348.2001.tb00115.x

Jørgensen L. N., Olsen L. V. 2007. Control of tan spot (Drechslera tritici-repentis) using cultivar resistance, tillage methods and fungicides. Crop Protection, 26 (11): $1606-1616$ http://dx.doi.org/10.1016/j.cropro.2007.01.009

Krupinsky J. M., Tanaka D. L. 2001. Leaf spot diseases on winter wheat influenced by nitrogen, tillage, and haying after a grass-alfalfa mixture in the conservation reserve program. Plant Disease, 85 (7): 785-789 http://dx.doi.org/10.1094/PDIS.2001.85.7.785
Krupinsky J. M., Halvorson A. D., Tanaka D. L., Merrill S. D. 2007 (a). Nitrogen and tillage effects on wheat leaf spot diseases in the Northern Great Plains. Agronomy Journal, 99 (2): 562-569

http://dx.doi.org/10.2134/agronj2006.0263

Krupinsky J. M., Tanaka D. L., Merrill S. D., Liebig M. A., Lares M. T., Hanson J. D. 2007 (b). Crop sequence effects on leaf spot diseases of no-till spring wheat. Agronomy Journal, 99 (4): 912-920 http://dx.doi.org/10.2134/agronj2006.0130s

Kutcher H. R., Johnston A. M., Bailey K. L., Malhi S. S. 2011. Managing crop losses from plant diseases with foliar fungicides, rotation and tillage on a Black Chernozem in Saskatchewan, Canada. Field Crops Research, 124: 205-212 http://dx.doi.org/10.1016/j.fcr.2011.05.018

Ronis A., Semaškiene R., Dabkevičius Z., Liatukas Ž. 2009. Influence of leaf diseases on grind yield and yield components in winter wheat. Journal of Plant Protection Research, 49 (2): 151-157 http://dx.doi.org/10.2478/v10045-009-0021-5

Sawinska Z., Malecka I., Blecharczyk A. 2006. Impact on previous crops and tillage systems on health status of winter wheat. Electronic Journal of Polish Agricultural Universities, 9 (4): 51

Schuh W. 1990. The influence of tillage systems on incidence and spatial pattern of tan spot of wheat. Phytopathology, 80 (9): 804-807 http://dx.doi.org/10.1094/Phyto-80-804

Simon M. R., Ayala F. M., Golik S. I., Terrile I. I., Cordo C. A., Perello A. E., Moreno V., Chidichimo H. 2011. Integrated foliar disease management to prevent yield loss in Argentinian wheat production. Agronomy Journal, 103 (5): 1441-1451 http://dx.doi.org/10.2134/agronj2010.0513

Wyczling D., Lenc L., Sadowski C. 2010. Comparison of disease occurrence and green leaf area (GLA) of winter wheat depending on the forecrop and differentiated fungicidal protection used. Journal of Plant Protection Research, 50 (4): 489-495

http://dx.doi.org/10.2478/v10045-010-0081-6 
ISSN 1392-3196 / e-ISSN 2335-8947

Zemdirbyste-Agriculture, vol. 102, No. 1 (2015), p. 67-72

DOI $10.13080 /$ z-a.2015.102.008

\title{
Žemès dirbimo būdo ir sẻjomainos įtaka žieminių kviečių lapų ligų vystymuisi
}

\author{
B. Bankina ${ }^{1}$, A. Ruža ${ }^{2}$, L. Paura ${ }^{3}$, I. Priekule ${ }^{4}$ \\ ${ }^{1}$ Latvijos žemès ūkio universiteto Dirvožemio ir augalų mokslų institutas \\ ${ }^{2}$ Latvijos žemès ūkio universiteto Agrobiotechnologijos institutas \\ ${ }^{3}$ Latvijos žemės ūkio universiteto Kontrolès sistemų skyrius \\ ${ }^{4} \mathrm{UAB}$,Makhteshim-Agan Benelux and Nordic“, Lietuva
}

\section{Santrauka}

Žieminiai kviečiai yra vieni pelningiausių žemès ūkio augalų. Pastaruoju metu išpopuliarèjo ịvairios auginimo technologijos, pavyzdžiui, minimalus žemès dirbimas ir kviečių atsèliavimas. Tyrimo tikslas - apibūdinti žieminių kviečių lapu ligų vystymąsi, priklausomai nuo žemès dirbimo būdo ir sèjomainos Vidurio Latvijos regiono sąlygomis. Bandymai vykdyti Latvijos žemès ūkio universiteto Peterlaukio mokomajame ir tyrimų ūkyje 2010, 2012 ir 2013 m. Bandymai vykdyti dviem blokais: 1) tradicinis žemės dirbimas taikant verstuvinį arimą 22-23 cm gyliu ir 2) minimalus žemès dirbimas taikant lèkštinį purenimą 10-12 cm gyliu. Kiekviename bloke buvo įrengtos skirtingos sejjomainos, tačiau sejjomainos rotacijos priklausomai nuo metų skyrèsi nedaug. Kviečių dryžligès infekcijos lygị padidino kviečių atsèliavimas ir minimalus žemės dirbimas, ypač kai šie du veiksniai taikyti kartu. Lapų septoriozès infekcijos lygiui turèjo įtakos žemès dirbimo būdas ir metai.

Reikšminiai žodžiai: minimalus žemės dirbimas, Pyrenophora tritici-repentis, Zymoseptoria tritici. 